\title{
Pola Pembinaan Keagamaan Anak Jalanan dalam Membentuk Kepribadian
}

\author{
Sari Famularsih \\ Institut Agama Islam Negeri (IAIN) Salatiga \\ email: sarifamularsih@yahoo.com \\ Arif Billah \\ Institut Agama Islam Negeri (IAIN) Salatiga \\ email:arifbillahbadr@gmail.com
}

\begin{abstract}
Abstrak
Artikel ini berusaha mengungkapkan tentang pentingnya pembinaan keagamaan untuk membentuk kepribadian anak jalanan yang identitasnya sebagai muslim yang kemudian ditunjukkan baik dalam perilaku dan kebiasaan. Banyak orang menganggap bahwa anak jalanan sebagai anakanak menjadi seperti kehidupan orang dewasa, bekerja dalam waktu yang panjang untuk mendapatkan uang dalam kondisi yang berbahaya baik untuk perkembangan fisik dan kesehatan mereka. Begitu pula berdampak terhapat hilangnya kesempatan mereka untuk mengenyam pendidikan. Penanaman keagamaan untuk anak jalanan secara perilaku lahiriyah seperti berjalan, makan, minum, berkomunikasi dengan orang tua, teman dan yang lainnya adalah hal-hal yang penting. Sebagai contoh perilaku kepribadian adalah tulus, tidak iri hati, dan perilaku terpuji lainnya. Pembinaan keagamaan yang ditujukan kepada anak-anak jalanan dimaksudkan untuk memupuk pandangan hidup yang stabil berdasarkan nilai-nilai keislaman yang kemudian dapat digunakan untuk berpikir, berperilaku berdasarkan norma Islam ataupun kepribadian yang berdasarkan pendidikan pemikiran Islam yang memiliki faktor-faktor dasar yang berbeda.
\end{abstract}


This article simply reveal about the importance of religious formation to form the personality of street children which is the identity of the individual has the hallmark of a moeslim, both shown in the behaviour and attitude of her inner outwardly. Some people judge the street children as a child too quickly into adult life, working for a long time to get a wage under conditions dangerous for their physical development and health, as well as miss access to education. The cultivation of the religious for the street children of lahiriyah behaviour such as walking, eating, drinking, communicating with parents, friends and others is very necessary. As examples of such inner Frank Burton Cheyne behavior, sincere, don't envy and other commendable attitude arising from within. The construction of the Islamic religion, addressed to children will be able to provide a steady view of life based on the values of Islam, was also able to get used to think, behave and behave according to the norms of Islam or personality in accordance with the teachings of Islam though has a different default factors.

Kata kunci: pembinaan, kepribadian, keagamaan

\section{Pendahuluan}

Manusia merupakan makhluk yang dilahirkan dalam keadaan lemah dan tidak berdaya, namun dengan demikian ia telah mempunyai potensi bawaan yang bersifat laten. Dalam perkembangannya manusia dipengaruhi oleh pembawaan dan lingkungan, dan salah satu sifat hakiki manusia adalah mencapai kebahagiaan, dan untuk mencapai kebahagiaan itu manusia membutuhkan agama (Ismail, 2001:219). Sejak dilahirkan anak membawa fitrah beragama, fitrah ini baru berfungsi setelah melalui proses bimbingan dan latihan. Fitrah dapat bermakna potensi untuk beragama, keinginan beragama, juga potensi untuk tidak beragama. Agama adalah aturan-aturan dari Tuhan Yang Maha Esa, petunjuk kepada manusia agar dapat selamat dan sejahtera/bahagia hidupnya di 
dunia dan akhirat dengan petunjuk serta teladan-teladan Nabi beserta kitabnya (Marimba, 1989:128).

Apabila manusia telah memilih suatu agama sebagai anutan, ia berkewajiban untuk melaksanakan ajaran dari perintah-perintah agama tersebut. Dalam pelaksanaan ajaran-ajaran agama, setiap pemeluk agama (Islam) diharapkan dapat melaksanakan atau mengamalkan ajaran-ajaran agamanya dalam kehidupan sehari-hari seperti adanya kewajiban untuk menjalankan ibadah shalat, puasa, zakat, dan haji. Bahkan bagi umat Islam seluruh kehidupannya idealnya adalah untuk beribadah kepada Allah. Sebagaimana tersebut dalam Qs. al-Dzariyat ayat 56 yang berbunyi :

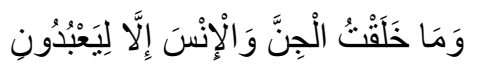

Artinya : "Dan tidak Aku ciptakan jin dan manusia itu kecuali hanyalah untuk beribadah kepada-Ku” (Qs. al-Dzariyat: 862).

Salah satu usaha untuk memahami dan mengamalkan agama dengan baik dan benar adalah melalui pendidikan yaitu pendidikan agama Islam. Adapun cara pendidikan untuk menanamkan dalam diri anak-anak nilai-nilai agama dan budaya islami yang benar, pendidik juga harus mengajarkan anak-anaknya moral Islami dan memberitahukan kepada mereka ketentuan-ketentuan syariat agama (M Zuaihaili, 2002: 64). Masyarakat juga berkewajiban memberikan pendidikan bagi anggotanya atau biasa disebut pendidikan yang bersifat informal. Memang diakui bahwa pengaruh masyarakat berperan besar dalam pembentukan kepribadian anak. Hal ini dikarenakan sosial budaya masyarakat mudah dijadikan acuan anak-anak dalam mencontoh 
perkataan dan perbuatannya, jika contoh yang diberikan oleh masyarakat itu positif maka generasi mudanya akan terpengaruh berperilaku dan berkepribadian positif pula. Selain masyarakat, sekolah dan lembaga sosial yang memberikan pendidikan harus memperhatikan pembinaan agama pada anak didiknya.

Agama Islam bukan sekedar puasa, zakat atau haji, melainkan juga berisi norma-norma dan nilai-nilai untuk berinteraksi dengan lingkungan sosialnya (orang tua, masyarakat dan alam sekitar). Dengan demikian materi yang diajarkan harus menyeluruh baik aspek aqidah, syariah dan akhlak sehingga tujuan pendidikan akan tercapai. Pembinaan agama Islam khususnya pembinaan yang dilakukan pada anak adalah untuk mengembangkan sikap, pengetahuan, daya cipta dan ketrampilan pada anak. Dalam konteks agama Islam dapat dicapai dengan berbagai metode pendidikan yang sangat menyentuh perasaan, mendidik jiwa dan mengembangkan semangat menjalankan agama (keberagamaan) pada anak sehingga menjadi anak yang saleh, beriman, taat beribadah, berakhlak terpuji (Zakiah Darojat, 1995: 40).

Berpijak pada uraian tersebut di atas, tulisan ini bermaksud menjelaskan pola pembinaan keagamaan anak jalanan dalam membentuk kepribadian. Rumusan masalah pada penelitian ini adalah bagaimana pola pembinaan keagamaan anak jalanan dalam membentuk kepribadian.

\section{Metode Penelitian}

Penelitian ini berbentuk penelitian kepustakaan (library research). Dalam penelitian ini, peneliti menggunakan metode analisis 
deskriptif. Analisis deskriptif adalah suatu metode dengan jalan mengumpulkan data, menyusun atau mengklasifikasi, menganalisis, dan menginterpretasikannya (Natsir: 1999) dengan tahapan-tahapan: (1) Mengumpulkan sumber referensi yang berkaitan dengan masalah yang diteliti serta mempelajarinya, (2) Setelah sumber referensi terkumpul diklasifikasikan data yang terdapat pada obyek penelitian dengan landasan teori yang telah diperoleh dari sumber-sumber referensi, dan (3) menganalisa dan menginterpretasikan mengenai topik permasalahan yang diteliti.

\section{Pembahasan}

Istilah bahasa pembinaan berarti usaha, tindakan dan kegiatan yang diadakan secara berdaya guna dan berhasil guna untuk memperoleh hasil yang lebih baik (Depdiknas,1990:37). Pembinaan juga dapat berarti suatu kegiatan yang mempertahankan dan menyempurnakan apa yang telah ada sesuai dengan yang diharapkan. Dari definisi tersebut dapatlah disimpulkan bahwa pembinaan adalah suatu usaha/kegiatan yang dilakukan untuk meningkatkan apa yang sudah ada kepada yang lebih baik (sempurna), baik dengan melalui pemeliharaan dan bimbingan terhadap apa yang sudah ada (yang sudah dimiliki) serta juga dengan mendapatkan hal yang belum dimilikinya yaitu pengetahuan dan kecakapan yang baru.

Pembangunan di bidang agama diarahkan agar semakin tertata kehidupan beragama yang harmonis, semarak dan mendalam. Serta ditujukan pada peningkatan kualitas keimanan dan ketakwaan terhadap 
Tuhan Yang Maha Esa, terpeliharanya kemantapan kerukunan hidup umat beragama dan bermasayarakat dan berkualitas dalam meningkatkan kesadaran dan peran serta akan tanggung jawab terhadap perkembangan akhlak serta untuk secara bersama-sama memperkukuh kesadaran spiritual, moral dan etika bangsa dalam pelaksanaan pembangunan nasional, peningkatan pelayanan, sarana dan prasarana kehidupan beragama.

Agama berasal dari Bahasa Sansekerta yang artinya tidak kacau, diambil dari dua suku kata "a" berarti tidak dan "gama" berarti kacau, secara lengkapnya agama ialah peraturan yang mengatur manusia agar tidak kacau (Dadang Kahmad, 2000: 21). Agama adalah aturan dari Tuhan, untuk petunjuk kepada manusia agar dapat selamat dan sejahtera atau bahagia hidupnya di dunia dan akherat dengan petunjuk-petunjuk serta pekerjaan nabi-nabi beserta kitab-kitab-Nya (Marimba, 1989:128).

Jadi agama adalah merupakan aturan-aturan atau perundangundangan yang datangnya dari Tuhan diturunkan kepada manusia sebagai pedoman hidup di dunia akherat agar memperoleh kebahagiaan di dunia dan akherat kelak. Agama sebagai refleksi atas cara beragama tidak hanya terbatas pada kepercayaan saja, tetapi juga merefleksi dalam perwujudan-perwujudan tindakan kolektivitas umat. Perwujudanperwujudan tersebut keluar sebagai bentuk dari pengungkapan cara beragama, sehingga agama dalam arti umum dapat diuraikan menjadi beberapa unsur, atau dimensi regiositas yaitu emosi keagamaan, sistem kepercayaan, sistem upacara keagamaan dan umat atau kelompokkelompok keagamaan (Muslim Kadir, 2002: 4). 
Agama befungsi untuk memelihara integritas manusia dalam membina hubungan dengan tuhan dan hubungan dengan sesama manusia dan dengan alam yang mengitarinya. Dengan kata lain, agama pada dasarnya berfungsi sebagai alat pengatur untuk terwujudnya integritas hidup manusia dalam hubungan dengan Tuhan dan hubungan dengan alam yang mengitarinya. Agama merupakan firman Tuhan yang diwahyukan kepada utusannya untuk disampaikan kepada umat.

Dalam pembinaan keagamaan bahwa yang menjadi dasar pembinaan adalah ajaran-ajaran yang ada dalam al-Qur'an dan al-Hadis yang semua telah difirmankan oleh Alah SWT dan telah disabdakan oleh Rasulullah SAW, sebagaimana tertulis di dalam al-Qur'an Qs. Ali Imran: 104.
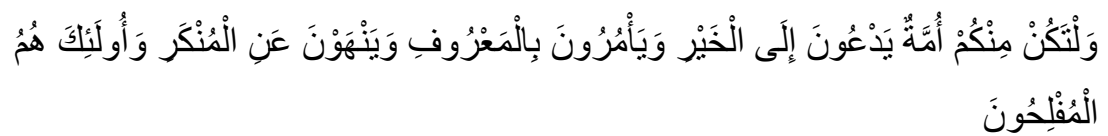

Artinya: "Dan hendaklah ada diantara kamu segolongan umat yang menyeru kepada kebajikan, menyuruh kepada yang makruf dan mencegah dari yang mungkar, merekalah orang-orang yang beruntung".(Qs. Ali Imran: 104)

Dari tujuan pembinaan adalah agar tercapainya kesempurnaan, artinya untuk mengadakan peningkatan dari yang sebelumnya. Bila sebelumnya kurang baik dan tidak sesuai dengan yang diinginkan. Dengan demikian tujuan dari pembinaan keagamaan adalah mewujudkan manusia yang mempercayai dan mengamalkan ajaran agama Islam dengan sepenuhnya. Peningkatan kualitas keimanan dan ketakwaan Terhadap Tuhan Yang Maha Esa diarahkan agar dapat menjiwai kehidupan bermasyarakat, berbangsa dan bernegara yang dilaksanakan 
melalui pemahaman dan pengamalan nilai-nilai spiritual, moral, dan etik keagamaan, sehingga terbentuk sikap batin dan sikap lahir yang setia (A Rahman Shaleh,2000:204).

Pengamalan berasal dari kata amal yang artinya perbuatan (baik atau buruk) yang mendapat awalan "pe" dan akhiran "an", yang berarti proses. Jadi pengamalan berarti proses perbuatan, melaksanakan, pelaksanaan, penerapan. Kemudian yang dimaksud dengan pengamalan keagamaan disini adalah bagaimana mengamalkan atau mengaplikasikan ajaran-ajaran agama Islam dalam kehidupan sehari-hari seperti sholat, puasa, zakat, haji, pergaulan hidup dalam masyarakat dan yang lainnya.

Status ini mengimplikasikan bahwa manusia secara potensial memiliki sejumlah kemampuan yang diperlukan untuk bertindak sesuai dengan ketentuan Tuhan, sebagai khalifah. Manusia juga mengemban fungsi Rububiyah Tuhan terhadap alam semesta termasuk diri manusia sendiri. Sesuai dengan ajaran agama maka pendidikan Islam bukan saja mengajarkan ilmu-ilmu sebagai materi, atau ketrampilan sebagai kegiatan jasmani semata, melainkan mengaitkannya semuanya itu dengan kerangka praktek (amaliyah) yang bermuatan nilai dan moral. Pendidikan Islam mengajarkan pencapaian keterpaduan antara aspek jasmaniah (lahiriyah) dan rohani (batiniyah), antara kehidupan dunia dan akhirat, dan antara kepentingan individual dan kepentingan kolektif, dan antara kedudukannya sebagai khalifah (wakil Allah) dan tugas sebagai 'abid (hamba Allah).

Untuk memenuhi semua kebutuhan hidup manusia, Islam memiliki tiga inti ajaran yang merupakan inti dasar ajaran Islam meliputi 
aqidah, syariah dan akhlak. Dasar-dasar ini terpadu menjadi satu dan merupakan bagian yang tak terpisahkan satu dengan yang lain (Zuhairini, 1995: 42).

Materi aqidah (tauhid) membahas tentang kepercayaan kepada ke-Esaan Allah SWT dan segala sesuatu yang berhubungan dengan keEsaan Allah SWT itu (rukun iman), berdasarkan dalil naqliyah maupun aqliyah (ratio) menurut kemampuan akal manusa yang dilandasi dengan iman (Matdawam,1995:6). Pada prinsipnya di dalam aqidah yang terpenting bukanlah pengetahuan tentang Allah, tetapi hubungan antara seseorang hamba dengan Allah yang akan timbul sikap dedikasi (rasa pengabdian, penyerahan). Dalam hal ini Islam merupakan anak tangga yang terakhir dan tertinggi karena ketegasannya tentang monotheisme yang mulus.

Doktrin tauhid (aqidah) bagi kehidupan manusia menjadi sumber kehidupan jiwa dan pendidikan kemanusiaan yang tinggi. tauhid akan mendidik jiwa manusia untuk mengikhlaskan seluruh hidup dan kehidupannya kepada Allah semata. Tujuan hidupnya ialah Allah dan harapan yang dikejarnya ialah keridhaan Allah. Oleh sebab itu membawa konsekuensi pembinaan karakter yang agung, menjadi manusia yang suci, jujur dan teguh memegang amanah.

Tauhid akan membebaskan manusia dari perasaan keluh kesah, bingung menghadapi persoalan hidup dan akan bebas dari rasa putus asa. Jadi tauhid memberikan kebahagiaan hakiki pada manusia di dunia dan kebahagiaan abadi di akherat kelak (Nazaruddin R,1998:42). 
Secara etimologi berarti jalan kemudian secara terminologi (qaidah syari'ah Islamiyah) berarti suatu sistem norma ilahiyah yang mengatur hubungan antara manusia dengan Tuhan, sesama manusia dan hubungan antar manusia dengan alam sekitarnya (E Saefudin Ansory,1989:90). Menurut Zuhairini, syari'ah berpusat pada dua segi yaitu segi hubungan manusia dengan Tuhannya yang bersifat ibadah dan segi hubungan manusia dengan sesamanya dan kemaslahatan hidupnya disebut muamalah. Keduanya sangat erat kaitannya dan tidak dapat dipisahkan antara satu dengan lainnya, dalam arti kedua-duanya harus bernilai ibadah dengan maksud dan tujuan manusia diciptakan.

Maka ibadah dan mu'amalah, dalam pengamalan ajaran Islam harus terpadu antara urusan pribadi dan masyarakat. Tidak ada di antara ajaran Islam yang hanya merupakan urusan pribadi dan tidak ada pula yang merupakan kepentingan masyarakat saja. Akhlaq atau etika menurut ajaran Islam meliputi hubungan dengan Allah (khaliq) dan hubungan dengan sesama makhluq (baik manusia maupun non manusia). Dengan ajaran akhlaq merupakan indikator kuat bahwa prinsip-prinsip ajaran Islam sudah mencakup semua aspek dan segi kehidupan manusia lahir maupun batin dan mencakup semua bentuk komunikasi, vertikal dan horizontal.

Pendidikan akhlaq yang berorientasi pada penanaman nilai luhur sebagai sifat dasar dalam menjamin hubungan dengan sesamanya sangat berkaitan dengan cara pandang dan watak dasar manusia. Untuk itulah akhlaq merupakan pokok esensi ajaran islam di samping aqidah dan syari'ah karena akan terbina mental dan jiwa seseorang untuk memiliki 
hakikat kemanusiaan yang tinggi dengan akhlaq dapat dilihat corak dan hakikat manusia yang sebenarnya:

Menurut ajaran Islam berdasarkan praktek Rasulullah, pendidikan akhlaqul karimah (akhlak mulia) adalah faktor penting dalam membina suatu umat atau membangun suatu bangsa. Suatu pembangunan tidaklah ditentukan semata dengan faktor kredit dan investasi materiil, betapapun melimpahnya kredit dan besarnya investasi.

Demikian pula pembangunan tidak mungkin berjalan hanya dengan kesenangan melontarkan fitnah pada lawan-lawan politik atau hanya mencari kesalahan orang lain. Yang diperlukan dalam pembangunan ialah keikhlasan, kejujuran, jiwa kemanusiaan yang tinggi, sesuainya kata dengan perbuatan, prestasi kerja, kedisiplinan, jiwa dedikasi dan selalu berorientasi kepada hari depan dan pembaharuan. Oleh karena itu program utama dan perjuangan pokok dari segala usaha ialah pembinaan akhlak mulia. Ia harus ditanamkan kepada seluruh lapisan dan tingkatan masyarakat, mulai dari tingkat atas sampai ke lapisan bawah, dari anak kecil sampai orang dewasa.

Dalam pembinaan terhadap anak jalanan memerlukan metode khusus dimana metode yang akan di gunakan harus menyesuaikan dengan karakter anak tersebut. Pengajaran yang penting untuk menstransfer pengetahuan atau kebudayaan untuk anak jalanan melalui metode pengajaran terjadi proses internalisasi dan pemilikan ilmu oleh pelajar, sehingga murid dapat menyerap apa yang telah disampaikan oleh gurunya dan memilikinya. Bilamana dikaitkan dengan pembinaan agama Islam, maka batasannya terletak pada metode atau teknik apakah yang 
lebih cocok digunakan dalam penyampaian materi agama tersebut agar tujuan pembelajaran yang ditetapkan dapat tercapai secara efektif dan efesien. Oleh sebab itu dapat disimpulkan bahwa metode pengajaran agama Islam adalah cara yang tepat dan cepat. Inilah yang sering diungkapkan dalam ungkapan efektif dan efisien.

Metode yang digunakan dalam pembinaan keagamaan sama halnya dengan pendidikan agama Islam. Meskipun demikian tidak semua metode mengajar di dalam kelas (pendidikan formal) dapat digunakan di luar kelas (pendidikan non formal) dalam hal ini pengajian kaum muslimin. Sebuah metode yang akan digunakan hendaklah jelas artinya yaitu menuju ke jalan Tuhan. Materi Pembinaan Agama Islam sebagai agama terakhir yang dibawa oleh Nabi Muhammad SAW. Sebagai utusan terakhir yang berfungsi sebagai rahmatan lil alamin yaitu rahmat dan nikmat bagi seluruh alam, utamanya bagi kehidupan manusia, sebagai risalah yang terakhir Islam memiliki nilai universal dan eternal, sesuai dengan kebutuhan manusia. Islam memiliki bentuk ajaran yang lebih sempurna dibanding ajaran sebelumnya. Pada hakekatnya agama Islam tidak lain adalah sebagai pemenuhan janji Tuhan bahwa akan memberikan petunjuk kepada manusia tentang bagaimana seharusnya manusia ini menempuh hidupnya secara wajar sehingga sejalan dan serasi dengan alam sekitarnya.

\section{Karakteristik Anak Jalanan}

Anak jalanan secara umum sebagai istilah yang dipakai untuk menyebutkan anak-anak yang menghabiskan sebagian besar waktunya 
dijalanan untuk mencari nafkah dengan berkeliaran di jalanan atau tempat-tempat umum lainnya. Kelompok ini sebagai suatu konstituen dari komunitas yang berada di jalan yang dalam hidup keseharian melakukan interaksi dengan berbagai elemen sosial yang ada di jalanan baik sesama anak maupun orang dewasa dengan berbagai latar belakang dan potensi yang berbeda.

Anak jalanan adalah anak-anak yang bekerja di jalan, studi yang dilakukan oleh Soedijar (1989/1990) menunjukkan bahwa anak jalanan adalah anak yang berusia antara 7-15 tahun yang bekerja di jalanan dan dapat mengganggu ketentraman dan keselamatan orang lain serta membahayakan dirinya sendiri. Sementara itu Direktorat Bina Sosial DKI menyebutkan bahwa anak jalanan adalah anak yang berkeliaran di jalan raya sambil bekerja mengemis atau menganggur saja. Panti Asuhan Klender mengatakan bahwa anak jalanan adalah anak yang sudah biasa hidup sangat tidak teratur di jalan raya, bisa sambil bekerja tetapi bisa juga hanya menggelandang sepanjang hari.

Sebagian masyarakat menilai anak jalanan sebagai anak yang terlalu cepat masuk ke dalam kehidupan orang dewasa, bekerja untuk waktu yang lama untuk mendapatkan upah di bawah kondisi yang berbahaya untuk kesehatannya dan perkembangan fisik mereka, serta ketinggalan akses pendidikan. Secara umum, defenisi anak jalanan dalam panduan Departemen Sosial RI (1999: iii), yaitu anak jalanan adalah anak yang menghabiskan sebagian besar waktunya untuk mencari nafkah dan berkeliaran di jalanan ataupun tempat-tempat umum lainnya, usia mereka sekitar 6 hingga 8 tahun dan beraktivitas minimal 4 jam sehari. 
Pendapat lain mendefinisikan bahwa anak jalanan adalah anak yang sudah biasa hidup tidak menentu di jalan raya atau tempat umum, bisa jadi sebagian di antaranya beraktivitas dengan jalan mengemis, mengamen, atau lap-lap mobil pada saat traffic light berwarna merah, tetapi yang lainnya bisa jadi hanya menggelandang sepanjang hari. Biasanya yang bekerja adalah mereka yang berusia 8 tahun ke atas (maksimal 18 tahun), namun yang masih kecil-kecil kebanyakan hanya bermain-main sambil menunggu para pengemudi kendaraan melemparkan koin ke dalam kaleng uangnya.

Berbagai definisi yang ada itu setidaknya menunjukkan adanya perbedaan mengenai usia dan batas pengertian. Mengenai usia sebenarnya PBB sudah menetapkan angka 18 tahun meski masingmasing negara masih berhak menentukan berdasar undang-undang masing-masing. Komunitas anak jalanan di Indonesia tentunya memberikan beragam corak interpretasi tentang pekerja anak.

Hidup menjadi anak jalanan bukanlah sebagai pilihan hidup yang menyenangkan, melainkan keterpaksaan yang harus mereka terima karena adanya sebab tertentu. Anak jalanan bagaimanapun telah menjadi fenomena yang menuntut perhatian banyak orang. Secara psikologis mereka adalah anak-anak yang pada taraf tertentu belum mempunyai bentukan mental emosional yang kokoh, sementara pada saat yang sama mereka harus bergelut dengan dunia jalanan yang keras dan cenderung berpengaruh negatif bagi perkembangan dan pembentukan kepribadiannya. Aspek psikologis ini berdampak kuat pada aspek sosial. Di mana labilitas emosi dan mental mereka yang ditunjang dengan 
penampilan yang kumuh, melahirkan pencitraan negatif oleh sebagian besar masyarakat terhadap anak jalanan yang diidentikkan dengan pembuat onar, anak-anak kumuh, suka mencuri, sampah masyarakat yang harus diasingkan. Pada taraf tertentu stigma masyarakat yang seperti ini justru akan memicu perasaan alienatif mereka yang pada gilirannya akan melahirkan kepribadian introvert, cenderung sukar mengendalikan diri dan asosial. Padahal tak dapat dipungkiri bahwa mereka adalah generasi penerus bangsa untuk masa mendatang.

Anak jalanan dilihat dari sebab dan intensitas mereka berada di jalanan memang tidak dapat disamaratakan. Dilihat dari sebab, sangat dimungkinkan tidak semua Anak Jalanan berada di jalan karena tekanan ekonomi, boleh jadi karena pergaulan, pelarian, tekanan orang tua, atau atas dasar pilihannya sendiri.

\section{Perkembangan Kepribadian Anak Jalanan}

Istilah kepribadian merupakan terjemahan dari Bahasa Inggris personality. Personality secara etimologis berasal dari bahasa latin person (kedok) dan personare (menembus) (John M Echols, 1996: 426). Kepribadian juga dapat dimaknai sebagai sifat hakiki yang tercermin pada sikap seseorang yang membedakannya dari orang lain. Pengertian kepribadian muslim secara terminologis sebagaimana dijelaskan Ahmad D. Marimba ialah kepribadian yang seluruh aspek-aspeknya yakni baik tingkah laku luarnya kegiatan-kegiatan jiwanya, maupun filsafat hidupnya dan kepercayaannya menunjukkan pengabdian kepada Tuhan penyerahan diri kepadanya (Marimba: 67). Sedangkan menurut Zakiah 
Daradjat kepribadian yang sesungguhnya adalah abstrak (ma'nawi) sukar dilihat atau diketahui secara nyata, yang dapat diketahui adalah penampilan atau bekasnya dalam segala segi dan aspek kehidupan. Misalnya dalam tindakan, ucapan, caranya bergaul, berpakaian dan dalam menghadapi masalah baik ringan ataupun berat. Kepribadian terpadu dapat menghadapi segala persoalan dengan sehat dan wajar karena segala unsur dalam pribadinya bekerja seimbang dan serasi (Dzakiah Darojat, 1995: 52).

Menurut Muhibbin Syah kepribadian pada prinsipnya adalah susunan atau kesatuan antara aspek perilaku mental (pikiran, perasaan, dan sebagainya) dengan aspek perilaku behavioral (perbuatan nyata). Aspek-aspek ini berkaitan secara fungsional dalam diri seseorang individu sehingga membuatnya bertingkah laku secara khas dan tetap (Muhhibin Syah, 2000: 225) Secara tidak langsung bahwa kepribadian merupakan kwalitas keseluruhan dari seseorang. Kwalitas tersebut akan tampak dalam cara-caranya berbuat, cara-caranya berpikir, cara-caranya mengeluarkan pendapat, sikapnya, minatnya, filsafat hidupnya serta kepercayaannya.

Pada dasarnya aspek-aspek kepribadian itu dapat digolongkan dalam tiga hal: (1) Aspek-aspek jasmaniah, meliputi tingkah laku luar yang mudah nampak dan ketahuan dari luar, misalnya: cara-caranya berbuat, cara-caranya berbicara dan sebagainya. (2) Aspek-aspek kejiwaan meliputi aspek-aspek yang segera dapat dilihat dan ketahuan dari luar, misalnya: cara-caranya berpikir, sikap (pendirian, pandangan) dan minat. (3) Aspek-aspek kerohanian yang luhur, meliputi aspek-aspek 
kejiwaan yang lebih abstrak yaitu filsafat hidup dan kepercayaan. Ini meliputi sistem nilai yang telah meresap di dalam kepribadian itu, yang telah menjadi bagian dan mendarah daging dalam kepribadian itu yang mengarahkan dan memberi corak seluruh kehidupan individu.

Sedangkan dalam pembentukan kepribadian dipengaruhi oleh beberapa faktor. Baik hereditas (pembawaan) maupun lingkungan. Berikut adalah faktor-faktor yang mempengaruhi kepribadian: (1) Fisik; faktor fisik yang dipandang mempengaruhi kepribadian adalah postur tubuh (langsing, pendek, gemuk atau tinggi) kecantikan, kesehatan, keutuhan, tubuh (utuh atau cacat) dan berfungsinya organ tubuh. Kondisi fisik yang berlainan itu menyebabkan sikap dan sifat-sifat serta temperamen yang berbeda-beda. (2) Intelegensi; faktor intelegensi individu yang tinggi atau normal biasanya mampu menyesuaikan diri dengan lingkungan secara wajar, sedangkan yang rendah biasanya sering mengalami hambatan dalam menyesuaikan diri dengan lingkungannya. (3) Keluarga; seorang anak yang dibesarkan dalam lingkungan yang harmonis dan agamis, maka kepribadian anak cenderung positif. Adapun anak yang dikembangkan dalam lingkungan keluarga yang adapun anak yang dikembangkan dalam lingkungan keluarga yang broken home, kurang harmonis, orang tua bersikap keras terhadap anak dan tidak memperhatikan nilai-nilai agama, amak perkembangan kepribadian cenderung akan mengalami, distorsi atau, mengalami kelainan dalam penyesuaian dirinya (maladjusment). (4) Teman sebaya (peer group); melalui hubungan interpersonal dengan teman sebaya anak belajar menilai dirinya sendiri dan kedudukannya dalam kelompok. Bagi anak 
yang kurang mendapat kasih sayang, bimbingan keagamaan dan etika dari orang tuanya, biasanya kurang memiliki kemampuan selektif dalam memilih teman dan mudah terpengaruh oleh sifat dan perilaku kelompoknya. Proses terjadi setelah mulai masuk-masuk sekolah. Berdasarkan kenyataan dilapangan, ternyata tidak sedikit anak yang menjadi perokok berat, peminum minuman keras, bergaul dengan bebas, karena pengaruh teman teman sebaya. (5) Kebudayaan; tradisi atau kebudayaan suatu masyarakat memberikan pengaruh terhadap kepribadian setiap anggotanya, baik menyangkut cara berpikir, bersikap pengaruh kebudayaan terhadap kepribadian dapat dilihat dari adanya perbedaan antara masyarakat modern dengan masyarakat primitif.

Perkembangan kepribadian menurut Ahmad D. Marimba mempunyai beberapa tahapan. Tahapan-tahapan itu ialah dengan cara melalui pembiasaan, pembentukan minat dan sikap dan pembentukan kerohanian yang luhur. Pembiasaan dimaksudkan ialah mendisiplinkan anak kepada tugas-tugas pribadi yang harus diselesaikan anak secara mandiri dari mulai hal yang paling sederhana sampai yang sulit. Contoh; waktu mandi, memberihkan kamar tidur, kebiasaan berkata sopan sampai mengerjakan tugas-tugas sekolah, mengaji, ke masjid dan lain-lain.

Pola selanjutnya adalah pembentukan minat. Minat adalah kecenderungan jiwa kepada sesuatu ada umumnya disertai rasa senang akan sesuatu. Dan bisa berkembang menjadi rasa kecintaan. Jika dalam masa perkembangan anak sudah didekatkan dengan keindahan, kebajikan, rasa sosial dan rasa ketuhanan akan menimbulkan rasa tertarik atau mempunyai kecendrungan pada hal-hal yang bersifat positif dalam 
kehidupannya kelak. Kemudian pendidikan sikap ialah pendidikan moal dan watak yang harus dimiliki dan dijadikan kebiasaa oleh anak sejak dini sampai dewasa. Sehingga anak tidak mempunyai akhlak atau sikap yang tercela dan yang terakhir adalam menanamkan kepercayaan agama atau rukun iman sejak dini. Hasilnya adalah kesadaran dan pengertian yang mendalam, segala yang dilakukan, diputuskan dan dilakun berdasarkan keyakinan dan dengan penuh rasa tanggung jawab dan pada akhirnya dari ketiga pola tersebut akan melahirkan anak dengan kepribadian yang sehat.

\section{Pembinaan Agama Islam dengan Perkembangan Kepribadian Anak}

Pembentukan kepribadian itu berlangsung secara berangsurangsur, bukan hal yang sekali jadi, melainkan sesuatu yang berkembang. Oleh karena itu pembentukan kepribadian merupakan suatu proses. Kepribadian terbentuk melalui semua pengalaman dan nilai-nilai yang diserap oleh anak, terutama pada masa perkembangannya. Apabila nilainilai agama banyak masuk ke dalam pembentukan kepribadian seseorang, maka tingkah laku orang tersebut akan banyak diarahkan dan dikendalikan oleh nilai-nilai agama. Disinilah letak pentingnya pengalaman dan pendidikan agama pada masa pertumbuhan dan perkembangan.

Hal ini didukung oleh teori mengenai kepribadian yang berpendapat bahwa tipe kepribadian ditentukan oleh aspek biologis seperti bentuk tubuh, kualitas sosial dan aspek psikologis yang menyangkut unsur kejiwaan yang dimiliki oleh seseorang. Kepribadian 
seseorang dapat dibentuk melalui bimbingan dari luar berupa pendidikan maupun pembinaan karena manusia mengalami proses belajar dalam hidupnya. Kenyataan ini memberikan peluang bagi usaha pendidikan maupun pembinaan dalam pembinaan kepribadian.

Pembinaan agama Islam diharapkan mampu membentuk identitas individu yang mempunyai ciri khas seorang muslim, baik yang ditampilkan dalam tingkah laku secara lahiriah maupun sikap batinnya. Tingkah laku lahiriyah seperti berjalan, makan, minum, berkomunikasi dengan guru, orang tua, teman dan lain-lainnya. Sedangkan tingkah laku batin seperti penyabar, ikhlas, tidak dengki dan sikap terpuji lainnya yang timbuldari dalam batin.

Dari berbagai pemikiran di atas maka pembinaan agama Islam yang ditujukan kepada anak akan mampu memberikan pandangan hidup yang mantap berdasar pada nilai-nilai Islam, juga mampu terbiasa berpikir, bersikap dan bertingkah laku menurut norma-norma Islam atau kepribadian yang sesuai dengan ajaran Islam walau mempunyai faktor bawaan yang berbeda.

Selanjutnya dari kepribadian tersebut mampu dipertahankan sebagai kebiasaan yang tidak dapat dipengaruhi oleh sikap dan tingkah laku orang lain yang bertentangan dengan apa yang dimiliki. Ciri khas tersebut hanya mampu dipertahankan jika sudah terbentuk dalam waktu yang lama atau mempunyai latar belakang yang lama dan tentunya dalam lingkungan yang baik terutama dari lingkungan keluarga.

Kepribadian secara utuh hanya mungkin dibentuk melalui pengaruh lingkungan khususnya pendidikan dengan sasaran mempunyai 
iman yang kuat dan akhlak yang mulia, dengan pemikiran bahwa iman adalah pengatur tingkah laku sedangkan akhlak adalah prwujudan dari iman yang berhubungan dengan sikap dan prilaku sehari-hari.

Menurut al-Ashqar, jika pembinaan agama Islam benar-benar berhasil maka anak akan mempunyai kepribadian dengan ciri-ciri berikut: (1) Selalu menempuh jalan hidup yang didasarkan didikan ketuhanan dengan melaksanakan ibadah. (2) Senantiasa berpedoman kepada petunjuk Allah. (3) Merasa memperoleh kekuatan untuk menyerukan dan berbuat benar dan menyampaikan kebenaran kepada orang lain. (4) Memiliki keteguhan hati. (5) Mempunyai kemampuan yang kuat dan tegas. (6) Tabah. (7) Memiliki kelapangan dan ketentraman hati. (8) Mengetahui tujuan hidup dan (9)Tobat jika melakukan kesalahan.

Kepribadian manusia juga memiliki dinamika yang unsurnya secara aktif ikut mempengaruhi aktivitas seseorang. Unsur-unsur tersebut ialah: (1) Energi rohaniah (psychis energy) yang berfungsi pengatur aktivitas rohaniah seperti berpikir, mengingat, mengamati dan sebagainya. (2) Naluri, yang berfungsi sebagai pengatur kebutuhan primer seperti makan, minum dan seks. Sumber naluri adalah kebutuhan jasmaniah dan gerak hati. Berbeda dengan energi rohaniah, maka naluri mempunyai sumber pendorong, maksud dan tujuan. (3) Ego (aku sadar) yang berfungsi untuk meredakan ketegangan dalam diri dengan cara melakukan aktivitas penyesuaian dorongan-dorongan yang ada dengan kenyataan obyektif (realitas). Ego meliki kesadaran untuk menyelaraskan dorongan yang baik yang baik dan buruk hingga tidak terjadi kegelisahan 
atau ketegangan batin. (4) Super ego yang berfungsi sebagai ganjaran batin baik berupa penghargaan (rasa puas, senang, berhasil) maupun berupa hukuman (rasa bersalah, berdosa, menyesal). Penghargaan batin diperankan oleh ego-ideal, sedangkan hukuman batin dillakukan oleh hati nurani.

Dalam kaitannya dengan tingkah laku, maka kepribadian manusia sebenarnya telah diatur semacam sistem kerja yang menyelaraskan tingkah laku manusia agar tercapai ketentraman dalam batinnya. Secara fitrah manusia terdorong untuk melakukan sesuatu yang baik, benar dan indah. Namun terkadang naluri mendorong manusia untuk segera memenuhi kebutuhannya yang bertentangan dengan realita yang ada. Misalnya dorongan untuk makan ingin dipenuhi, tetapi makanan tidak ada (realitas), maka timbul dorongan untuk mencuri. Jika perbuatan itu dilakukan, maka Ego (aku sadar) akan merasa bersalah, karena mendapat hukuman dari Ego-ideal (norma agama) sebaliknya jika dorongan untuk mencuri tidak dilaksanakan maka Ego akan memperoleh penghargaan dari hati nurani.

Pemenuhan dorongan pertama akan menyebabkan terjadi kegelisahan pada Ego, sedangkan pemenuhan dorongan kedua akan menjadikan Ego tenteram. Dengan demikian, kemampuan Ego untuk menahan diri tergantung dari pembentukan Ego-ideal. Dalam kaitan inilah bimbingan dan pendidikan agama sangat berfungsi bagi pembentukan kepribadian seseorang. Pendidikan moral dan akhlak ini adalah dalam upaya membekali Ego-ideal dengan nilai-nilai luhur. Pembentukan Ego-ideal ini terbentuk oleh lingkungan baik di keluarga 
maupun masyarakat, sedangkan peletak dasarnya adalah orang tua. Kemudian pendapat, Zakiah Daradjat menganalisis masalah pembinaan agama kaitannya dengan pembinaan mental. Sejak anak dilahirkan kedunia, mulailah ia menerima didikan-didikan dan perlakuan-perlakuan. Mula-mula dari ibu bapaknya, kemudian dari anggota keluarga yang lain, semuanya itu ikut memberikan dasar-dasar pembentukan kepribadiannya. Pembinaan dan pertumbuhan kepribadian itu kemudian ditambah dan disempurnakan oleh sekolah.

Pendidikan agama pada pada masa anak-anak dilakukan dengan metode pembiasaan kepada tingkah laku dan akhlak yang diajarkan oleh agama. Dalam menumbuhkan kebiasaan akhlak karimah seperti jujur, adil, sopan dan sebagainya orang tua harus memberikan contoh, karena anak ini mempunyai sifat meniru apa yang dia lihat. Apabila anak telah terbiasa berbuat baik maka akan tertanamlah rasa itu ke dalam jiwanya dan menjadi salah satu unsur kepribadiannya. Demikian pula nilai-nilai agama dan kaidah-kaidah sosial yang lain, sedikit demi sedikit masuk dalam perkembangan mentalnya.

Apabila pembinaan agama itu tidak diberikan kepada anak sejak kecil, maka akan sukarlah baginya untuk menerima apabila ia dewasa, karena dalam kepribadiannya yang terbentuk sejak kecil itu tidak terdapat unsur-unsur agama. Jika dalam kepribadian itu tidak ada nilai-nilai agama, akan mudahlah orang melakukan segala sesuatu menurut dorongan dan keinginan jiwanya tanpa mengindahkan kepentingan dan hak orang lain. Ia selalu didesak oleh keinginan dan kebutuhan yang pada dasarnya tidak mengenal batas-batas, hukum dan norma. Tetapi jika 
dalam kepribadiannya tertanam nilai-nilai agama maka segala keinginan dan kebutuhannya akan dipenuhi dengan cara yang tidak melanggar hukum, karena jika ia melanggar akan goncang jiwanya karena tindakannya tidak sesuai dengan kepribadiannya. Maka pembinaan agama pada anak benar-benar akan menjadi kontrol pribadi terhadap sikap dan perbuatannya. Dari berbagai paparan pendapat para pakar diatas dapat disimpulkan bahwa pembinaan Agama akan membentuk kepribadian anak.

\section{Kesimpulan}

Pendidikan agama pada pada masa anak-anak dapat dilakukan dengan metode pembiasaan kepada tingkah laku dan akhlak yang diajarkan oleh agama. Dalam menumbuhkan kebiasaan akhlak karimah seperti jujur, adil, sopan santun. Perkembangan kepribadian anak mulai dari mendapatkan materi pendidikan kepribadian, sampai pada taraf pembiasaan dan juga selalu memantau prilaku sehari-hari anak sehingga prilaku yang anak yang baik dapat dipertahankan dan prilaku yang kurang baik bahkan tidak baik dapat segera diketahui dan diluruskan dengan demikian akan tercipta kepribadian anak yang sehat dan harmonis.

Dalam pembiasaan beribadah dalam arti khusus (ibadah wajib) maupun ibadah umum beserta ilmu-ilmunya seperti diharuskan membaca al-Qur'an dengan artinya, diajari tajwid, diterangkan makna yang terkandung, dan tadarus bersama, diadakan kegiatan rutin pengajian, diajarkan sholat, puasa, dan rukun Islam lainnya dan juga diajarkan 
akhlaqul karimah sehingga anak akan menjadi seorang yang berkepribadian muslim ideal.

\section{Daftar Pustaka}

Anshori, Endang Syaifuddin. 1989. Kuliah al-Islam. Yogyakarta: CV Rajawali.

Arief, Armai. 2002. Pengantar Ilmu dan Metodologi Pendidikan Islam. Jakarta: Ciputat Pers.

Asrohah, Harun. 2002. Sejarah Pendidikan Islam. Jakarta: PT Logos Wacana Ilmu.

Daradjat, Zakiah. 1995. Pendidikan Islam dalam Keluarga dan Sekolah. Jakarta: Ruhama. . 1996. Ilmu Jiwa Agama. Jakarta: PT Bulan Bintang. 2001. Kesehatan Mental. Jakarta: Toko Gunung

Agung.

Depag RI. Al-Qur'an dan Terjemahannya. Semarang: CV. Asy-Syifa'. Departemen Pendidikan dan Kebudayaan. 1990. Kamus Besar Bahasa Indonesia. Jakarta: Balai Pustaka.

Departemen Pendidikan Nasional. 2002. Kamus Bahasa Indonesia, Edisi Ketiga. Jakarta: Balai Pustaka.

Echols, John M. dan Hassan Shadily. 1996. Kamus Inggris Indonesia. Jakarta: PT. Gramedia.

Jalaluddin dan Usman Said. 1996. Filsafat Pendidikan Islam. Jakarta: PT. Raja Grafindo Persada.

Jalaluddin, H. 2002. Psikologi Agama. Jakarta: PT Raja Grafindo Persada

Kadir, Muslim A. 2002. Ilmu Islam Terapan. Yogyakarta: Pustaka Pelajar.

Kahmad, Dadang. 2000. Metode Penelitian Agama. Bandung: Pustaka Setia.

Marimba, Ahmad D. 1989. Pengantar Filsafat Islam. Bandung: Al Ma'arif.

Bandung: Al-Ma'arif.

1989. Pengantar Filsafat Pendidikan Islam. 
Matdawam, M. Noor. 1995. Aqidah dari Ilmu Pengetahuan dalam Lintasan Sejarah Dinamika Budaya Manusia. Yogyakarta: Yayasan "Bina Karier" LPSBIP.

Mukhtar, Maksum. 2001. Madrasah Sejarah dan Perkembangannya. Jakarta: Logos Wacana Ilmu.

Muslim. tt. Shohih Muslim, Jilid IV. Libanon: Darul Fikr, Beirut.

Nata, H. Abuddin. 1997. Filsafat Pendidikan Islam. Jakarta: Logos Wacana Ilmu.

Proyek Pembinaan Prasarana dan Sarana PT Agama/IAIN. 1984 / 1985.

Metodik Khusus Pengajaran Agama Islam. Jakarta:

Purwanto, Ngalim. 1996. Psikologi Pendidikan. Bandung: Remaja Rosda Karya.

Razak, Nasruddin. 1989. Dienul Islam. Bandung: Al-Ma'arif.

Shaleh, Abdul Rachman. 2000. Pendidikan Agama dan Keagamaan, Misi Visi dan Aksi. Jakarta: PT Gemawindu Panca Perkasa.

SM., Ismail Et. All. 2001. Paradigma Pendidikan Islam. Yogyakarta: Pustaka Pelajar.

Soetopo, Hendyat dan Wanty Soemanto. 1982. Pembinaan dan Pengembangan Kurikulum. Jakarta: Bina Aksara.

Syah, Muhibbin. 2000. Psikologi Pendidikan dengan Pendekatan Baru. Bandung: Remaja Rosda Karya.

Tafsir, Ahmad. 1995. Metodologi Pengajaran Agama Islam. Bandung: PT Remaja Rosda Karya.

Tim Penyusun Kamus Pusat Pembinaan Dan Pengembangan Bahasa. 1993. Kamus Besar Bahasa Indonesia. Jakarta: Balai Pustaka.

Ulwan, Abdullah Nashih. 1999. Pendidikan Anak dalam Islam. Jakarta: Pustaka Amani.

Usman, Basyiruddin. 2002. Metodologi Pembelajaran Agama Islam. Jakarta: Ciputat Pers.

Wahjoetomo. 1979. Pendidikan Alternatif Masa Depan. Jakarta: Gema Insani Press.

Zuhaili, Muhammad. 2002. Pentingnya Pendidikan Islam Sejak Dini, Jakarta:

Zuhairini dkk. 1995. Filsafat Pendidikan Islam. Jakarta: Bumi Aksara. 